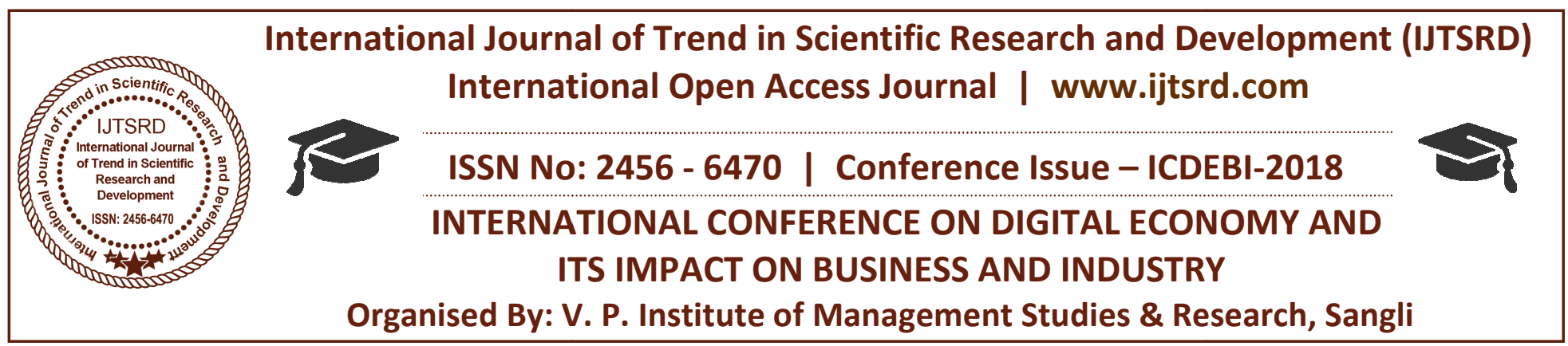

\title{
Role of Mobile Banking in Selected Areas of Karad
}

\author{
Santosh. B. Potadar ${ }^{1}$, Dr. R. V. Kulkarni ${ }^{2}$ \\ ${ }^{1}$ Assistant Professor, Willigndon College, Sangli, Maharashtra, India \\ ${ }^{2} \mathrm{Head}$ of the Department, CSIBER, Kolhapur, Maharashtra, India
}

\begin{abstract}
The mobile banking is a provision of banking services to customers on their mobile devices. Mobile phones and handheld devices should have been firmly established as an alternative form of payment in most technologically advanced societies. Mobile banking allows customers to conduct financial transactions on a secure mobile app operated by their retail or virtual bank. Mobile banking solutions have many features and capabilities. The Key intention of the study is to evaluate those factors that manipulate the nature of the customers towards mobile banking and on growing tendency towards the online financial institutions. This paper focuses on problems and study and solutions to banking industry to get a benefit from rural areas bank customers to explore banking industry. It provides recommendation for better role of Mobile Banking in rural area customers.
\end{abstract}

KEYWORD: Mobile Banking, Mobile App, Virtual Bank, Rural Area

\section{INTRODUCTION}

Today we are in the era of globalization. Multinational organizations worldwide have adopted globalization as their first strategic choice. Advancement in technology has facilitated globalization too. The world has literally shrunk become a "global village". Internet banking arrived in India in the late 1990s.

ICICI was the first bank to champion its usage and introduced internet banking to its customers in 1996 with lower internet costs and increased awareness about electronic media, online banking established itself only in 1999. Other banks followed suit, including HDFC, Citibank, IndusInd and the now redundant Times Bank. Internet banking changed both the banking industry as well as banks' services to its customers.

'Anywhere banking' came to be recognized as an opportunity also for differentiated and competitive services. E-Banking in remote rural areas of India is encouraging. It will become one of the most convenient ways of delivering financial services in the future. Over the last few years online banks have started to become more and more popular. There are plenty of reasons for this but there are still quite a few people who are not sure if an online account is a good idea for them. In short, the objective of this study is to examine the illiteracy and concerns of rural areas specifically in karad area bank customer to use mobile banking. The study shows customers' awareness, perception, and the level of satisfaction with regard to mobile banking system. It leads to a solution for banking industry as well as rural areas bank customers in many perspectives. Generally internet mobile is widely used in urbanized area. But in case of rural region mobile banking is not used or it is used in very low scale. The rural area bank customers are not using net banking facility due to some reasons which are studied further ahead.

\section{Statement of the Research Problem}

Consumer's behavior in banking changed partly as a result of change in the amount of spare time available to individuals. Mobility, independence of time, place and flexibility has become key words in banking.

The features of Mobile Banking such as 24 hours and 7 days availability, almost immediate access and the absence of physical borders. Indeed, the Internet has 
been one of the key drivers in promoting mobile banking sector. Thus to study the awareness and illiteracy of mobile banking in rural areas, the topic attempted is "Role of Mobile Banking in selected Rural areas of Karad"

\section{Objectives of the study}

1. To Study the present status of mobile banking use in selected areas of karad.

2. To study the reliability and satisfaction of mobile Banking users.

3. To study the Mobile Banking provides sufficient services to customers for fulfill their banking needs

\section{Review of Literature}

3"Obstacles Towards Adoption of Mobile Banking in Tanzania: A Review “, Joel D. Rumanyika [1],Work focuses on the obstacles towards the adoption of mbanking in Tanzania It has been observed poor network coverage, lack of knowledge of mobile banking users, lack of enough floats, ATMs breakdown and theft, poor security of mobile network are critical obstacles towards the adoption of mobile banking in Tanzania.

"A Study on Customer Perception towards mobile banking in Indian overseas bank", Palani A; Yashodha, P [2] The study revealed that education, gender, income plays an important role in the usage of mobile banking. Inhibitory factors like trust, gender, culture, religion, security and price has an impact on customer mindset towards mobile banking to a little extent.

"Acceptance of E-banking among adult customers: an empirical investigation in India", Dixit Neha, Dr Saroj Datta [3] The research paper has tried to examine the factors affecting the acceptance of e-banking services among adult customers. The findings show that security, privacy, trust, innovativeness, familiarity etc could increase the acceptance of E-banking service among customers.

"A survey of critical success factors in e-Banking: an organisational perspective", Shah Hussain Mahmood, Braganza Ashley and Morabito Vincenzo [4] The research showed that organisations need to manage their Ebanking initiative at a strategic level and treat it as business critical rather than simply a technical or operational issue. They need to pay attention to internal integration, which includes channels, technology and business process integration, and improving the overall services to their customers.

"Microfinance interventions and customer perceptions: a study of rural poor in Punjab" Meenu, Arora Sangeeta [5] This paper is an empirical study carried out in the rural areas of Punjab to find out how far the micro financing services have been successful to meet the financial needs of the rural poor and its impact on the ultimate borrowers

"Bank on Rural India- way to economic development", NSN Reddy, Chief Manager, Andhra Bank HO, Hyderabad [6] With various data base on Indian GDP sect oral contribution, rural income patterns etc, the author has emphasized that India's growth is driven by its service sector and economic development so far has been limited only to urban population and yet to penetrate the rural areas. Studying the income, expenditure, literacy rates and various other factors, the author has supported his views saying that the banking I rural area needs a relook as their needs are beyond traditional products.

\section{Sampling methodology}

The present study has been completed using Field Survey and Interview methods. In the survey the researcher has approached customer. For this purpose questionnaire are designed. Empirical data is collected from the samples of selected areas of karad through Purposive Sampling Method.

\section{Data Collection Method}

Data selection method is based on nature, scope and ready to give information etc. Data is collected by using primary and secondary methods.

\section{Primary Data}

Questionnaire method for collecting data is used for this study. This method is most suitable for collected same data from large number of user. A comprehensive questionnaire with various questions are divided under different sections. Each section is designed to collect data about certain topic of Mobile banking. Data is collected through questionnaires from Personal Interview, Survey etc.

\section{Secondary Data}

The Secondary data has been collected from Websites, Reports, Books, Journals, News Papers and Magazines. 
International Journal of Trend in Scientific Research and Development (IJTSRD) ISSN: 2456-6470 | IF: 4.101

\section{Sampling Plan}

In karad city there are 26 wards from which five wards are selected randomly using Lottery Method from each ward 50 samples are taken for study then total size becomes 250 but actually data was available from five wards 220 respondents were selected from each ward by using purposive sampling method.
VI. Hypothesis of the study

For the research purpose, the researcher has designed following hypothesis:

H0 Mobile Banking not provides sufficient services to fulfil their banking needs.

\section{Data Analysis and Interpretation}

Table 1: Demographic Characteristics of Respondents

\begin{tabular}{|c|c|c|c|c|}
\hline Sr. No. & Variable & Responses & No. of Respondents & Percentage \\
\hline \multirow{2}{*}{1} & \multirow{2}{*}{ Gender } & Male & 143 & 65 \\
\hline & & Female & 77 & 35 \\
\hline \multirow{4}{*}{2} & \multirow{4}{*}{ Age } & Below 20 yrs & 44 & 20 \\
\hline & & 21 to $35 \mathrm{yrs}$ & 77 & 35 \\
\hline & & 36 to $50 \mathrm{yrs}$ & 66 & 30 \\
\hline & & Above 50 yrs & 33 & 15 \\
\hline \multirow{4}{*}{3} & \multirow{4}{*}{ Education } & Matriculate & DI/COC & 0 \\
\hline & & Under Graduate & 00 & 10 \\
\hline & & Graduate & 121 & 55 \\
\hline & & Post Graduate & $77 \quad 0$ & 35 \\
\hline \multirow{6}{*}{4} & \multirow{4}{*}{ Occupation } & Businessman & $55 \Omega$ & 25 \\
\hline & & Employee & $66-3$ & 30 \\
\hline & & Farmer & Jour11 & 5 \\
\hline & & House Wife & 22 & 10 \\
\hline & \multirow{2}{*}{0} & Pensioner & 33 & 15 \\
\hline & & Student $/ r C$ & and 33 & 15 \\
\hline \multirow{2}{*}{5} & \multirow{2}{*}{ Bank Type } & Nationalized & 88 & 40 \\
\hline & & Private & Melt: 132 & 60 \\
\hline \multirow{4}{*}{6} & \multirow{4}{*}{ Account Type } & Saving & 158 & 53.4 \\
\hline & & Current & 647061 & 20.6 \\
\hline & & FD & $27 \times$ & 9.1 \\
\hline & & $\begin{array}{l}\text { Demat } \\
\text { Loan }\end{array}$ & $\begin{array}{l}34 \\
16\end{array}$ & $\begin{array}{c}11.5 \\
5.4\end{array}$ \\
\hline
\end{tabular}

Table 2: Bank Customer Perspective about Mobile Banking

\begin{tabular}{|c|c|c|c|c|c|}
\hline & $\begin{array}{c}\text { Strongly } \\
\text { Agree }\end{array}$ & Agree & Neutral & $\begin{array}{c}\text { Strongly } \\
\text { Disagree }\end{array}$ & Disagree \\
\hline Mobile Banking performance and poor network & 0 & 5 & 35 & 55 & 5 \\
\hline Mobile Banking is a better way of Banking & 40 & 50 & 5 & 5 & 0 \\
\hline Mobile Banking simple and easy registration procedure & 20 & 70 & 10 & 0 & 0 \\
\hline $\begin{array}{c}\text { Mobile Banking useful for conducting banking } \\
\text { transaction }\end{array}$ & 70 & 30 & 0 & 0 & 0 \\
\hline $\begin{array}{c}\text { Mobile Banking allows to manage finance more } \\
\text { efficiently }\end{array}$ & 45 & 40 & 10 & 0 & 5 \\
\hline Fear of hacking Mobile Banking Account & 0 & 25 & 35 & 5 & 35 \\
\hline $\begin{array}{c}\text { Afraid of loose money while Mobile Banking due to } \\
\text { careless mistakes }\end{array}$ & 0 & 50 & 15 & 20 & 15 \\
\hline $\begin{array}{c}\text { To perceive Mobile Banking as secure and protect } \\
\text { privacy }\end{array}$ & 20 & 35 & 30 & 15 & 0 \\
\hline Mobile Banking mostly used services & 25 & 5 & 40 & 5 & 25 \\
\hline
\end{tabular}


International Journal of Trend in Scientific Research and Development (IJTSRD) ISSN: 2456-6470 | IF: 4.101

\begin{tabular}{|c|c|c|c|c|c|}
\hline Mobile Banking services is a part of life & 15 & 50 & 25 & 10 & 0 \\
\hline $\begin{array}{c}\text { Mobile Banking allows me to do my banking } \\
\text { anywhere/anytime }\end{array}$ & 30 & 60 & 10 & 0 & 0 \\
\hline \begin{tabular}{c} 
Factors of Mobile Banking adoption \\
\hline
\end{tabular} & 25 & 20 & 15 & 30 & 10 \\
\hline
\end{tabular}

\section{Hypothesis Testing}

H0: Mobile Banking not provides sufficient services to fulfil the banking needs.

Table Mobile Banking provides sufficient services to customers for fulfill their banking needs

\begin{tabular}{|c|c|c|}
\hline Response & $\begin{array}{c}\text { No. of } \\
\text { Respondents }\end{array}$ & Percentage \\
\hline Strongly Agree & 66 & 30 \\
\hline Agree & 99 & 45 \\
\hline Neutral & 33 & 15 \\
\hline Disagree & 22 & 10 \\
\hline $\begin{array}{c}\text { Strongly } \\
\text { Disagree }\end{array}$ & 0 & 0 \\
\hline Total & 220 & 100 \\
\hline
\end{tabular}

Fig Mobile Banking provides sufficient services to customers for fulfill their banking needs

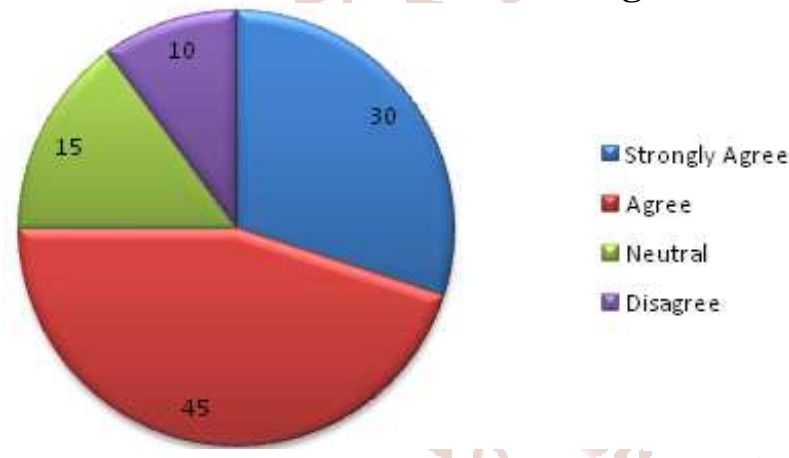

The majority of the respondents i.e. $90 \%$ using Mobile Banking are agree with that Mobile Banking provides sufficient services to customers for fulfill their banking needs

\begin{tabular}{|c|c|c|c|}
\hline & Value & df & $\begin{array}{c}\text { Asymp. Sig. } \\
\text { (2-sided) }\end{array}$ \\
\hline $\begin{array}{c}\text { Pearson Chi- } \\
\text { Square }\end{array}$ & $23.907^{\mathrm{a}}$ & 3 & .000 \\
\hline $\begin{array}{c}\text { Likelihood } \\
\text { Ratio }\end{array}$ & 34.340 & 3 & .000 \\
\hline $\begin{array}{c}\text { N of Valid } \\
\text { Cases }\end{array}$ & 220 & & \\
\hline
\end{tabular}

a. 0 cells (_.- \%) have expected count less than 5 . The minimum expected count is 7.70 .
Symmetric Measures

\begin{tabular}{|c|c|c|c|}
\hline \multicolumn{2}{|c|}{} & Value & $\begin{array}{c}\text { Approx. } \\
\text { Sig. }\end{array}$ \\
\hline $\begin{array}{c}\text { Nominal by } \\
\text { Nominal }\end{array}$ & Phi & .330 & .000 \\
\cline { 2 - 4 } & Cramer's V & .330 & .000 \\
\hline
\end{tabular}

a. Not assuming the null hypothesis.

b. Using the asymptotic standard error assuming the null hypothesis.

With SPSS as an analysis package,

Calculated $x^{2}$ is 23.907 and Tabulated $x^{2}$ is 12.838

Calculated value of Chi-Square is $>$ than Tabulated value of Chi-Square. Therefore Null Hypothesis HO is rejected.

That means the alternative Hypothesis is

Mobile Banking provides sufficient services to fulfill the banking needs.

\section{Findings and Results}

1. The observed evidences of this study reveal that gender, age, education and occupation of the mobile banking users plays significant role in adapting Mobile Banking services.

2. National sector banks private sector banks have more customers are using Mobile Banking services.

3. Proportion of saving accounts is significantly very large as compare to Current, FD, Loan and Demat accounts.

4. Majority of the respondents using Mobile Banking are agreeing with that the performance of Mobile Banking is dependent on network.

5. Majority of the respondents using Mobile Banking are agreeing with that the Mobile Banking is better way of banking.

6. Mobile Banking users are agreeing with that the Mobile Banking simple and easy registration procedure.

7. All respondents using Mobile Banking are agreeing with that the Mobile Banking useful for conducting banking transaction.

8. Majority of the respondents are using Mobile Banking services allows managing finance more efficiently through Mobile Banking. 
9. From all respondents using Mobile Banking services $35 \%$ respondents have a fear of hacking Mobile Banking Account.

10. The majority of the respondents using Mobile Banking are Afraid of loose money while Mobile Banking due to careless mistakes.

11. From all respondents using Mobile Banking services $15 \%$ are disagree with Mobile Banking as secure and protect privacy.

12. Mobile Banking provides different services to users but most of the customers uses services like A/C Balance Enquiry, Bill Payment, Money Transfer between A/C only $5 \%$ uses A/C Statement Enquiry, Other Mobile Banking services.

13. Majority of the customers using Mobile Banking services are disagree with that the Mobile Banking services is a part of life.

14. All of the respondents using Mobile Banking services have allows to users do banking anywhere/anytime.

15. Majority customers are adopted Mobile Banking services because of different factors like Accomplish task more quickly i.e.25\%, Any Time Banking i.e.20\%, Built-in help facility i.e. $15 \%$, Functions fulfill Banking needs i.e.30\%, Security i.e. $10 \%$.

16. The majority of the respondents i.e. $90 \%$ using Mobile Banking are agree with that Mobile Banking provides sufficient services to customers for fulfill their banking needs.

\section{Conclusion}

For mobile banking awareness banks should take some responsive steps like in arranging Workshop, Mobile Banking Training Program and Advertising.

To develop a Mobile Banking learning Web Site and App which helps to provides training and guide lines to non mobile Banking users.

Arrange a customer interaction session in which customers can clear their queries and doubts regarding mobile banking registration, security and privacy.

Create awareness regarding importance of mobile banking in case of conducting mobile banking transaction and show them how it saves your time and money by doing anytime and anywhere banking.

Develop mobile banking apps which work on low configuration mobile and on poor network also.

\section{REFERENCES}

1. Abrams,M. Jajodia, S; Podell, H, June 1995, "Information Security An integrated Collection of Essays“, IEEE Computer Society Press, vol 2, pno. 25

2. Aycock, John, January 2006 ,“Computer Viruses and Malware” Springer pno.26

3. Butler W. Lampson, January 2004, "Computer Security in the Real World", Principles of Computer Systems, vol. 1,. P. no. 76

4. Burnett, Mark, Kleiman, Dave. , July 2006, "Perfect Passwords" Rockland: Syngress Publishing, vol 2.

5. Cohen, Fred, June 1984, "Computer Viruses Theory and Experiments" IBM, vol2 pno.53

6. Cohen, Fred, April 1984, “An Undetectable Computer Viruses”, IBMp.21 Michael Gibson, "Overview Virus classification www.wikidoc.org/index.php/ Virus_classification, 2009

7. Cortada, James W, April 2004, "How Computers Changed the Work of American Public Sector Industries” Oxford University Press, vol. 2, ,p.no 48.

8. Denning, Dorothy E., May 1986, "An Intrusion Detection Model," Proceedings of the Seventh IEEE Symposium on Security and Privacy, p.no 13.

9. Denning, December 1998, “Computer Under Attack Intruder, Worm And Viruses" Addison Wisely, p. 28

10. Fred Cohen, October 1988,"On the implications of Computer Viruses and Methods of Defense" IBM, , p.35

11. J Jurgens du Toit, November 2007, “Resolving eassesments issues security using agents" MS Thesis, University of Johannesburg, pno 33.

12. James D. Feist and Dale R. McCullough, APR 2010, "Behavior Patterns and Communication in Feral Horses” International Journal of Behavioral Biology, vol.3, , P.no 67

13. Lunt, Teresa F., November 1993, "Detecting Intruders in Computer Systems," Conference on Auditing and Computer Technology, SRI International, ,pno. 88 
International Journal of Trend in Scientific Research and Development (IJTSRD) ISSN: 2456-6470 | IF: 4.101

14. Morris, Robert; Thompson, Ken, June 1978, "Password Security: A Case History" NJ, USA: Bell Laboratories, , p. 5

15. Michael Kaiser ,April 17, 2009 ,"Small and Medium Size Businesses are Vulnerable", National Cyber Security, vol 2, , p.46

16. Pfleenger, C, October1997, "Security in Computing" NJ: Prentice Hall, vol3, pno.23

17. Robert C. Newman., 19 February 2009, "Computer Security: Protecting Digital Resources” Jones \& Bartlett Learning, ,pno 35.
18. Standards for Technology in Automotive Retail ,July 2010, “Types Of Malicious Software”, http://www.starstandard.org/

19. Scarfone, Karen; Mell, Peter . ,February 2007,"Guide to Intrusion Detection and Prevention Systems (IDPS)". National Institute of Standards and Technology vol2, , pno. 44

20. Teng, Henry S., Chen, Kaihu, and Lu, Stephen CY, May 1990, "Adaptive Real-time Anomaly Detection Using Inductively Generated Sequential Patterns," IEEE Symposium on Security and Privacy, pno 102

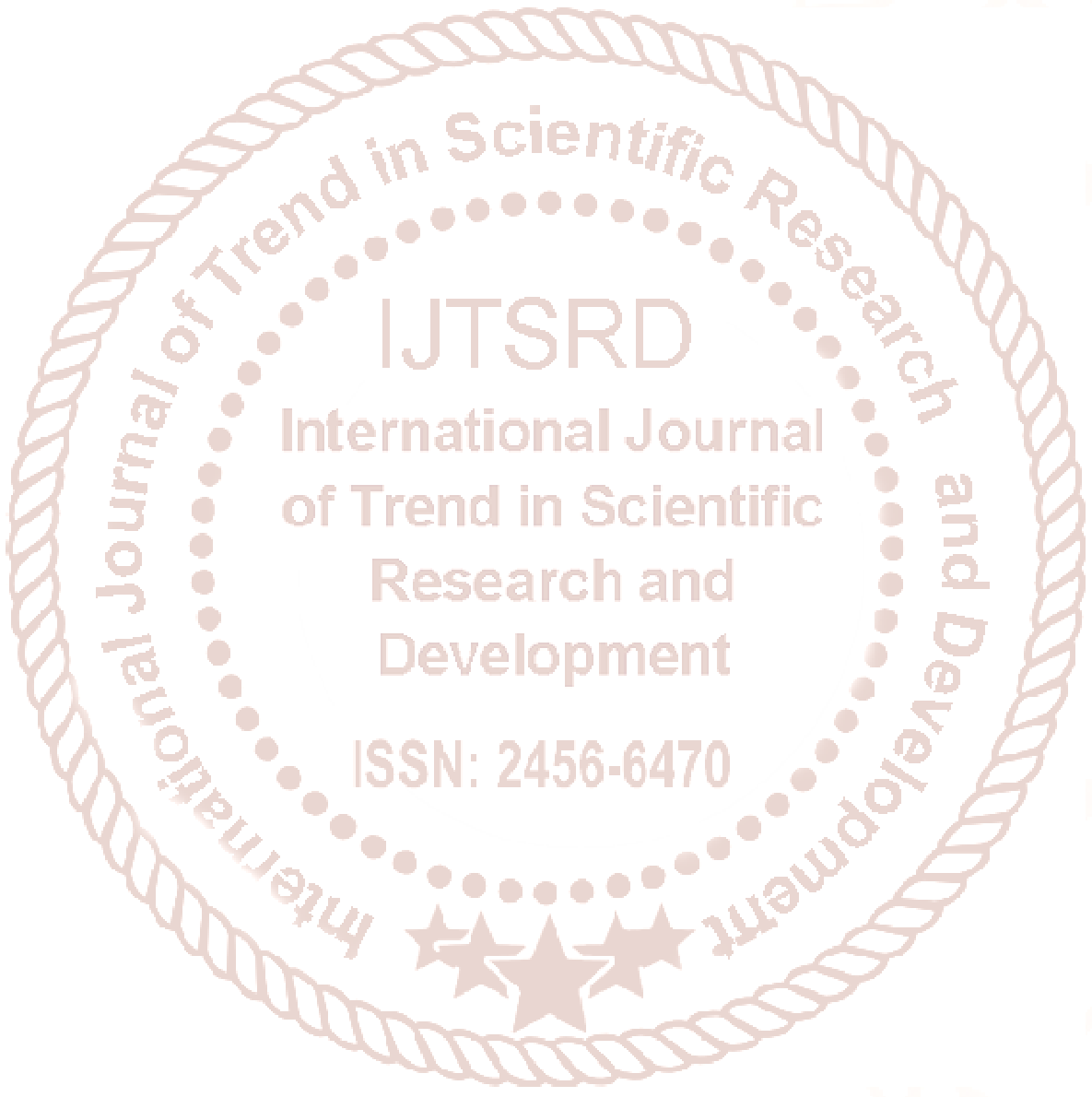

